\title{
HAZARD ASSESSMENT OF CURRENT STATE OF VEGETATION DEGRADATION USING GIS, A CASE STUDY: SADRA REGION, IRAN
}

\author{
MASOUD MASOUDI ${ }^{1^{*}}$, E. AMIRI $^{2}$ \\ ${ }^{1}$ Associate Professor at Department of Desert Region Management, College of Agriculture, Shiraz University, Iran \\ ${ }^{2}$ Department of Environment in Fars Province, Shiraz , Iran
}

\begin{abstract}
The entire land of Southern Iran faces problems arising out of various types of land degradation of which vegetation degradation forms one of the major types. The present work introduces a model developed for assessing the current status of hazard of vegetation degradation using Geographic Information System (GIS). This kind of assessment differs from those assessments based on vulnerability or potential hazard assessments. The Sadra watershed which covers the upper reaches of Marharlu basin, Fars Province, has been chosen for a hazard assessment of this type of degradation. The different kinds of data for indicators of current status of vegetation degradation were gathered from collecting of field data and also records of the governmental offices of Iran. Taking into consideration three indicators of current status of vegetation degradation the model identifies areas with different hazard classes. By fixing the thresholds of severity classes of the three indicators including per cent of vegetation cover, biomass production and ratio of actual biomass to potential biomass production, a hazard map for each indicator was first prepared in GIS. The final hazard map of current status of vegetation degradation was prepared by intersecting three hazards in the GIS. Results show areas under severe hazard class have been found to be widespread (89\%) while areas under moderate and very severe hazard classes have been found less extensive in the Sadra watershed. The preparation of hazard maps based on the GIS analysis of these indicators will be helpful for prioritizing the areas to initiate remedial measures.
\end{abstract}

Keywords: Vegetation Degradation, GIS, Indicator, Hazard map, current state.

\section{INTRODUCTION}

Hazard is something that is dangerous. Usually it means a potentially adverse situation that may occur tomorrow, next week or 10 years from now (Bridge et al. 2001). But hazard of vegetation degradation or other natural resources hazards like erosion does not belong or happen not only in future but also in current time. Therefore to assess current state of hazard, the estimates reflect what has happened till date and is assessed by direct observation and expert judgment.
Vegetation degradation results in reduction in the available biomass, and decline in the vegetative cover. In contrast to deforestation, which has been defined as "the clearance of forest for agriculture or other purposes", vegetation degradation refers to "the temporary or permanent reduction in the density, structure, species composition or productivity of vegetation cover". The definition shows that the reduction implied is not only in the quantity of biomass but also in its quality; for instance

\section{Open Access http://dx.doi.org/10.5141/ecoenv.2013.006}

This is an Open Access article distributed under the terms of the Creative Commons Attribution Non-Commercial License (http://creativecommons. org/licenses/by-nc/3.0/) which permits unrestricted non-commercial use, distribution, and reproduction in any medium, provided the original work is properly cited.
Received 03 February 2013, Accepted 25 February 2013

*Corresponding Author

E-mail: masoudi@shirazu.ac.ir

Tel: +98 7112287159 
increasing of bush over rangelands, and the loss of palatable pasture grasses and their replacement with nonpalatable species (Masoudi 2005). Vegetation degradation is a major factor contributing to soil erosion and loss of soil organic matter, but it is assessed as an individual type of land degradation in some methods of assessment of desertification hazard (FAO/UNEP 1984). Other studies like GLASSOD (Global Assessment of Soil Degradation (Oldeman et al. 1991)) and ASSOD (Assessment of Soil Degradation (Van Lynden \& Oldeman 1997)) do not consider vegetation degradation as an individual type of land degradation, which is one of the disadvantages.

Compared to other countries in the Middle East, the present status of land degradation in Iran is alarming as about $94 \%$ of arable lands and permanent pastures are estimated to be in the process of degradation (FAO 1994). This includes the large proportion of land that has already been affected by vegetation degradation which forms one of the major types of land degradation in Iran. Degradation of the vegetation due to cultivation, grazing, and collecting of fuel in many regions of Iran reached a stage when one would believe it was beyond any repair. That is why evolving a model, such as the present one, for assessing the hazard of vegetation degradation is extremely important.

Anthropogenic activity like agriculture, overgrazing, deforestation, mining and urbanization are known to harm the natural vegetation cover. Expansion of land under agriculture ruins the biodiversity of natural vegetation cover. Farmers desert these lands once the productivity lowers. Thus a rangeland subjected to wrong land use turns to a bare land becoming more sensitive to faster soil degradation.

Deforestation, over grazing and encroachment to rangelands is indulged by the rural population for fuel and construction material, food for their livestock, and for increasing the land under agriculture. The correlation between desertification hazards and the rural population density is obvious in most developing countries but not in the industrial countries where the rural population is low (Le Houerou 1996).

Livestock has always been blamed for land degradation. As vegetation cover declines under heavy stocking, the water infiltration rate decreases and the wind and water erosion increases (Mwendera and Mohamed Saleem 1996, Le Houerou 1996, Asadu and et al. 1999, Taddese 2001). The grazing action of livestock especially sheep and goat, damages the surface soil.

Natural hazards like water erosion, soil salinization, and drought also decrease the vegetation cover. The veg- etation cover on land depends also on its soil characteristics. Soils with good condition are better covered than soils with limitations like salinity, bad drainage, erosion, shallow depth, and topography. Variation in annual rainfall is a big threat for vegetation cover. Areas with major fluctuations in annual rainfall have higher $\mathrm{CV}$ for annual rainfall, compared to other areas with less fluctuation. Therefore the CV of annual rainfall serves as an indicator to show the drought hazard. The vegetation cover of agricultural lands and natural resources has a greater risk of damage in such zones.

An Environmental hazard like vegetation degradation generally includes three aspects: a) current state of hazard b) Potential of hazard (inherent risk) c) Trend of hazard. Using different indicators we can estimate these aspects of a hazard (FAO/UNEP 1984). The hazard assessment of vegetation degradation has been done in the present paper on the basis of three indicators showing current status of degradation.

\section{MATERIALS AND METHODS}

Study Area: The Study area, Sadra region, is located in the western part of Maharlu basin, Fars Province, Southern Iran. The region is bounded between Latitude $29^{\circ}, 40^{\prime}$ and $29^{\circ}, 56^{\prime} \mathrm{N}$ and Longitude $52^{\circ}, 10^{\prime}$ and $52^{\circ}, 24^{\prime}$ E. Fig. 1 indicates the location of the region in the basin and in Iran. It covers an area of nearly 25,112 ha, including different sub-regions of Ghalat, Dokohak, Gooyum, Ashayer, and Ghomshe with 35,202 residents in 2006. The region lies in the semi-arid climate and receives only a precipitation less than $500 \mathrm{~mm}$, annually.

Data gathering: The data obtained were of two types 1) thematic maps and 2) field gathering data showing current state of natural vegetation cover (Table 1). All relevant data to No. 1 were obtained from the local and main offices and institutes of the Ministries of Agriculture and Energy and Organizations of Management \& Planning and Meteorology of Iran and processed and digitized thoroughly, using the GIS technique (Software of Arc View 3.2). The thematic maps were digitized and some numerical data related to them have been considered to further prepare different hazard maps.

For assessing map of potential biomass production, annual precipitation and land suitability maps have been used. First it was evaluated using Bonham equation (1) with emphasizing on annual precipitation (Bonham 1989) and it was revised with land suitability map to show role of soil characteristics on production (Table 2). 


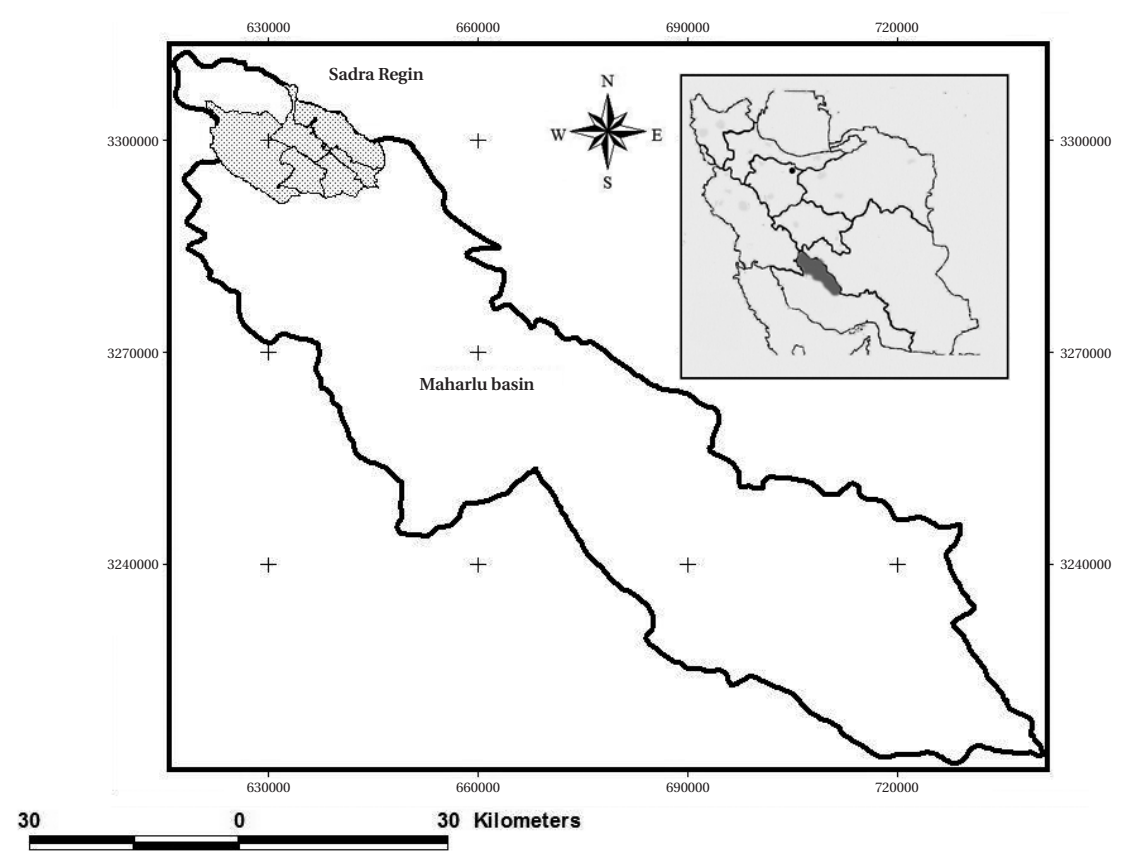

Fig . 1. Location Map of Maharlu Basin in Iran

Table 1. Field gathering samples showing current state of natural vegetation cover.

\begin{tabular}{|c|c|c|c|c|c|}
\hline $\begin{array}{l}\text { Sam- } \\
\text { ples }\end{array}$ & $\begin{array}{c}\text { Biomass } \\
\text { production } \\
\text { (dry matter- } \\
\text { Kg/ ha/year) }\end{array}$ & $\begin{array}{l}\text { Percent of } \\
\text { vegeta- } \\
\text { tion } \\
\text { cover }\end{array}$ & $\begin{array}{l}\text { Sam- } \\
\text { ples }\end{array}$ & $\begin{array}{c}\text { Biomass } \\
\text { production } \\
\text { (dry matter- } \\
\mathrm{Kg} / \text { ha/year) }\end{array}$ & $\begin{array}{c}\text { Percent of } \\
\text { vegeta- } \\
\text { tion } \\
\text { cover }\end{array}$ \\
\hline 1 & 560 & 21.5 & 31 & 472 & 16.2 \\
\hline 2 & 722 & 30.2 & 32 & 294 & 16.2 \\
\hline 3 & 1166 & 30.2 & 33 & 538 & 16.2 \\
\hline 4 & 462 & 30.2 & 34 & 370 & 15.3 \\
\hline 5 & 656 & 21.5 & 35 & 786 & 21.9 \\
\hline 6 & 402 & 30.2 & 36 & 572 & 25.9 \\
\hline 7 & 888 & 19.8 & 37 & 1050 & 25.9 \\
\hline 8 & 470 & 19.8 & 38 & 620 & 25.9 \\
\hline 9 & 1548 & 30.2 & 39 & 570 & 25.9 \\
\hline 10 & 1400 & 34.2 & 40 & 624 & 25.9 \\
\hline 11 & 1832 & 34.2 & 41 & 450 & 15.2 \\
\hline 12 & 790 & 24.5 & 42 & 278 & 15.2 \\
\hline 13 & 398 & 19.5 & 43 & 412 & 15.2 \\
\hline 14 & 886 & 19.5 & 44 & 296 & 15.2 \\
\hline 15 & 802 & 19.5 & 45 & 592 & 20.5 \\
\hline 16 & 360 & 17.0 & 46 & 912 & 20.5 \\
\hline 17 & 730 & 17.0 & 47 & 574 & 20.5 \\
\hline 18 & 482 & 21.9 & 48 & 706 & 20.5 \\
\hline 19 & 758 & 21.9 & 49 & 452 & 20.5 \\
\hline 20 & 830 & 21.9 & 50 & 436 & 20.5 \\
\hline 21 & 1104 & 32.6 & 51 & 476 & 20.5 \\
\hline 22 & 482 & 24.5 & 52 & 782 & 19.7 \\
\hline 23 & 670 & 24.5 & 53 & 928 & 19.7 \\
\hline 24 & 740 & 24.5 & 54 & 432 & 19.7 \\
\hline 25 & 402 & 20.6 & 55 & 374 & 19.7 \\
\hline 26 & 602 & 20.6 & 56 & 338 & 19.7 \\
\hline 27 & 490 & 20.6 & 57 & 1334 & 42.8 \\
\hline 28 & 516 & 20.6 & 58 & 924 & 42.8 \\
\hline 29 & 556 & 16.2 & 59 & 1366 & 42.8 \\
\hline 30 & 594 & 16.2 & 60 & 1006 & 42.8 \\
\hline
\end{tabular}

Bio $=3.89 \times(\mathrm{P})^{1.09}$

Bio: amount of biomass production (Kg per hectare per year) ; P: annual precipitation (mm)

But the data related to current state of natural vegetation cover including per cent of vegetation cover and actual (current) biomass were gathered from different rangeland types (Fig. 2) in the study area during field working. It should be pointed that forest area is not observed in the study area. To gather these kinds of data, first rangeland areas were divided to different homogenous land units based on different soil types, rangeland types and variation in topography. It is tried to have at least one sample (plat of $1 \times 5 \mathrm{~m}$ ) for each land unit and for larger units more data based on statistical methods of sampling, were gathered. Also horizontal distance $(5 \mathrm{~m})$ of each plat was corrected because $5 \mathrm{~m}$ distance on each map is more in the sloppy lands. Therefore to correct this problem,

Table 2. Revised Biomass based on soil characteristics (Masoudi, 2005).

\begin{tabular}{lll}
\hline Revised Biomass & $\begin{array}{l}\text { Land Suitability for } \\
\text { Natural Vegetation } \\
\text { Cover }\end{array}$ & $\begin{array}{l}\text { Soil } \\
\text { Limitations }\end{array}$ \\
\hline Bio' $^{\prime}=$ Bio +0.25 Bio & Good: $\mathrm{S}_{1}, \mathrm{~S}_{2}$ & No \\
Bio' $^{\prime}=$ Bio $-0.25 \mathrm{Bio}$ & Moderate: $\mathrm{S}_{3}$ & Moderate \\
Bio' $^{\prime}=$ Bio -0.5 Bio & Low: $\mathrm{S}_{4}$ & High \\
Bio' $=$ Bio -0.75 Bio & Not suitable: $\mathrm{N}_{1}, \mathrm{~N}_{2}$ & Very high \\
\hline
\end{tabular}




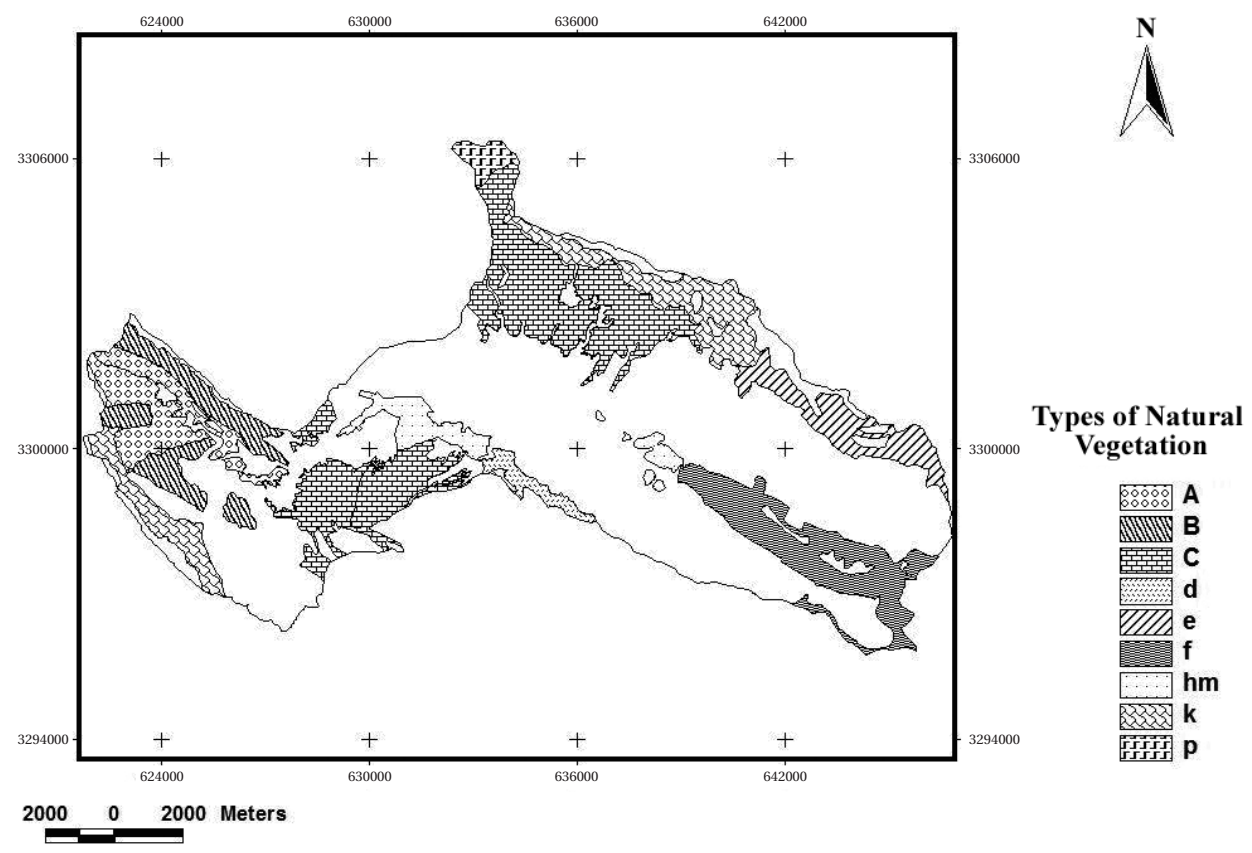

Fig. 2. Different types of natural vegetation cover in the study area.

(A: Amygdalus-Astrgalus-Phlomis; B: Astragalus-Convolvulus; C: Artemisia-Lactuca; d: Astragalus-Lactuca; e: Lactuca-Convolvulus; f: Astragalus-AmygdalusConvulus; hm: Carthamus-Alhagi-Astragalus; k: Astragalus; p: Astragalus-Centauvea-Artemisia)

Pythagoras theorem equation (2) was used for the sloppy samples to reach to the real horizontal distance of plats.

$$
R=\sqrt{(L)^{2}+(\Delta H)^{2}}
$$

R: real horizontal distance, L: horizontal distance on map $=5 \mathrm{~m}, \Delta H$ : increase in elevation of each sample based on its slope

Finally 60 samples (Table 1) for 23 different land units were gathered and their data have been considered in the produced land unit map for the further GIS analysis.

Method of hazard map preparation: The assessment of the hazard of vegetation degradation has been attempted by first identifying the main indicators of current status of vegetation degradation and then establishing the thresholds (class limits) of severity for indicators and in the end analyzing the hazard. The recommendations appear- ing in some literature (like Le Houerou \& Le Hoste 1977, FAO/UNEP 1984, Kharin 1986, Kumar 1992, Masoudi, 2005) have been taken into consideration while fixing the thresholds of the five classes of severity (ratings scores between 1 to 5) for each indicator. The following three indicators (Table 3) have been processed in the GIS to arrive at the hazard map for each indicator. Hazard map of indicator 2, biomass production, was assessed based on FAO/ UNEP classification (1984). To prepare this hazard map, current biomass production map derived from field gathering data was compared separately in different rainfall parts of the region taking into consideration of their land suitability for vegetation cover (Table 4).

In order that the effect of all the indicators gets projected in the hazard map, the overlays of the individual hazard maps, derived from three indicators, were analyzed step by step. The severity of hazard assigned to

Table 3. Indicators Used in the GIS Model of Hazard Assessment for Current State of Vegetation Degradation

\begin{tabular}{lccccc}
\hline \multicolumn{1}{c}{ Indicators } & \multicolumn{3}{c}{ Class limits and their score } \\
\cline { 2 - 6 } & None & $\begin{array}{c}\text { Slight } \\
\text { (1) }\end{array}$ & $\begin{array}{c}\text { Moderate } \\
\text { (3) }\end{array}$ & $\begin{array}{c}\text { Severe } \\
\text { (4) }\end{array}$ & $\begin{array}{c}\text { Very severe } \\
\text { (5) }\end{array}$ \\
\hline $\begin{array}{l}\text { 1) Per cent of vegetation cover } \\
\text { 2) Biomass production (dry matter- Kg/ ha/ }\end{array}$ & $\geq 70$ & $50-69.9$ & $25-49.9$ & $10-24.9$ & $<10$ \\
$\quad \begin{array}{l}\text { year/lmm of precipitation) } \\
\text { 3) Ratio of actual biomass to Potential biomass } \\
\text { production }\end{array}$ & - & $\geq 5$ & $2.5-4.9$ & $1-2.4$ & $<1$ \\
\hline
\end{tabular}




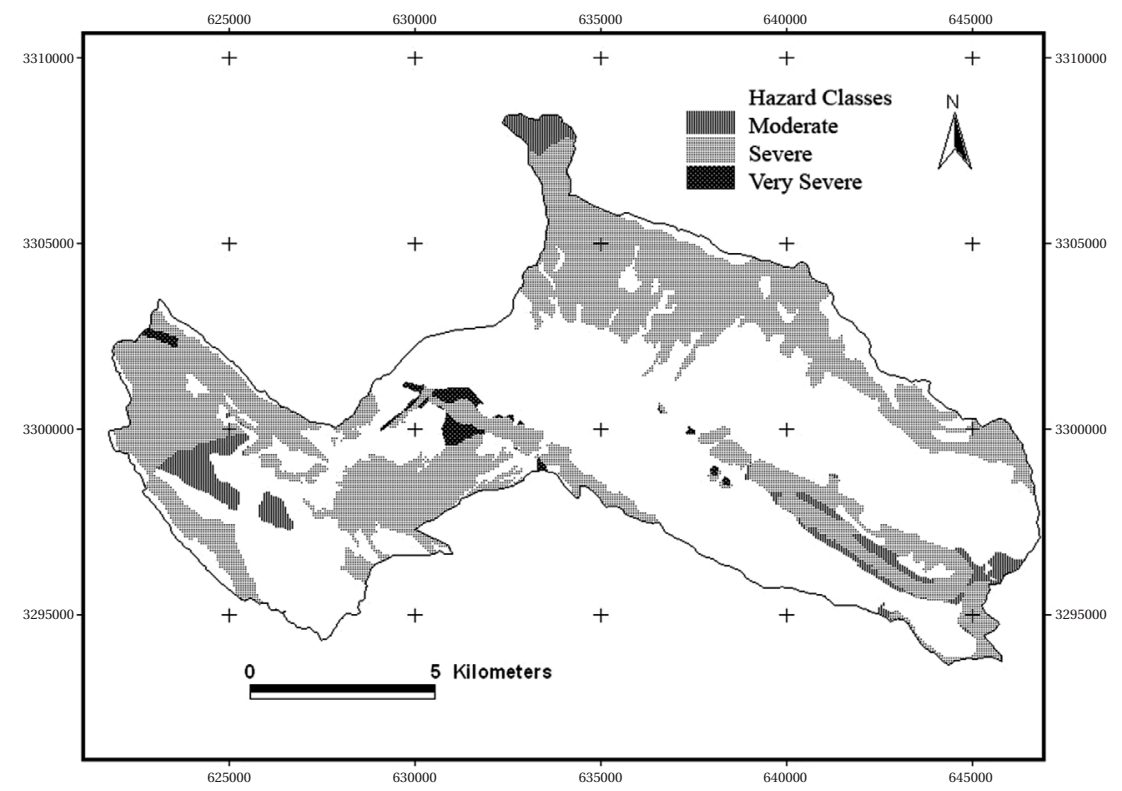

Fig. 3. Hazard of Current Status of Vegetation Degradation in the Sadra Basin

Table 4. The Severity Classes of Biomass Production (dry matter- Kg/ ha/year) based on using average of annual precipitation and land suitability in the study area

\begin{tabular}{|c|c|c|c|c|}
\hline \multicolumn{5}{|c|}{ Average of annual precipitation $=425 \mathrm{~mm}$} \\
\hline $\begin{array}{l}\text { Land } \\
\text { suitability }\end{array}$ & Slight & Moderate & Severe & $\begin{array}{c}\text { Very } \\
\text { severe }\end{array}$ \\
\hline S3 & $1593 \leq$ & $1593-796$ & $796-318$ & $318>$ \\
\hline S4,S5 & $1065 \leq$ & $1065-531$ & $531-212$ & $212>$ \\
\hline $\mathrm{N} 1, \mathrm{~N} 2$ & $531 \leq$ & 531-265 & $106.25-265$ & $106.25>$ \\
\hline \multicolumn{5}{|c|}{ Average of annual precipitation $=475 \mathrm{~mm}$} \\
\hline $\begin{array}{c}\text { Land } \\
\text { suitability }\end{array}$ & Slight & Moderate & Severe & $\begin{array}{c}\text { Very } \\
\text { severe }\end{array}$ \\
\hline S3 & $1781 \leq$ & $1781-890$ & $890-356$ & $356>$ \\
\hline S4,S5 & $1187 \leq$ & $1187-593$ & $593-237$ & 237> \\
\hline $\mathrm{N} 1, \mathrm{~N} 2$ & $593 \leq$ & $593-296$ & 296-118 & $296>$ \\
\hline \multicolumn{5}{|c|}{ Average of annual precipitation $=550 \mathrm{~mm}$} \\
\hline $\begin{array}{c}\text { Land } \\
\text { suitability }\end{array}$ & Slight & Moderate & Severe & $\begin{array}{c}\text { Very } \\
\text { severe }\end{array}$ \\
\hline S3 & $2062 \leq$ & $2062-1031$ & $1031-412$ & $412>$ \\
\hline S4,S5 & $1375 \leq$ & $1375-687$ & $687-275$ & $275>$ \\
\hline $\mathrm{N} 1, \mathrm{~N} 2$ & $678 \leq$ & $687-343$ & $343-137$ & $137>$ \\
\hline \multicolumn{5}{|c|}{ Average of annual precipitation $=650 \mathrm{~mm}$} \\
\hline $\begin{array}{c}\text { Land } \\
\text { suitability }\end{array}$ & Slight & Moderate & Severe & $\begin{array}{c}\text { Very } \\
\text { severe }\end{array}$ \\
\hline S3 & $2437 \leq$ & $2437-1218$ & $1218-487$ & $487>$ \\
\hline S4,S5 & $1625 \leq$ & $1625-812$ & $812-325$ & $325>$ \\
\hline $\mathrm{N} 1, \mathrm{~N} 2$ & $812 \leq$ & $812-406$ & $406-162$ & $162>$ \\
\hline
\end{tabular}

each polygon has been assessed by summing all the attributes (rating scores) of indicators used in the GIS. Such a method has been conventionally used for preparing the hazard and risk maps for different types of land degradation (Grunblatt et al. 1992, Kumar 1992, Singh et al. 1992, Ahmadi 1995, Ahmadi et al. 2001, Feiznia et al. 2001, and Zehtabian \& Jafari 2002).

The following equation (3) was used for each polygon to produce final hazard map in GIS:

Score of Current State of Hazard $=$ (Score of per cent of vegetation cover + Score of biomass production + (Score of Ratio of actual biomass to Potential biomass production $\times 1.5)) / 3.5($ Eq.3)

Indicator of "Ratio of actual biomass to Potential biomass production" was given a weight of 1.5 because of its important rule for describing the current state of hazard but two other indicators weight of 1 were given. Therefore Score of Current State of Hazard in the Equation 3 was divided to 3.5 .

The hazard score in each polygon denotes the cumulative effect of all the indicators for qualifying the five severity classes (Table 5). This facilitated the production of Fig. 3 that showed the different degrees of current state of vegetation degradation.

Table 5. The Severity Classes of Hazard Map of Vegetation Degradation Produced in the GIS.

\begin{tabular}{cccccc}
\hline Class & None & Slight & Moderate & Severe & Very severe \\
Hazard score & $1.0-1.49$ & $1.50-2.49$ & $2.5-3.49$ & $3.5-4.49$ & $4.5-5.0$ \\
\hline
\end{tabular}




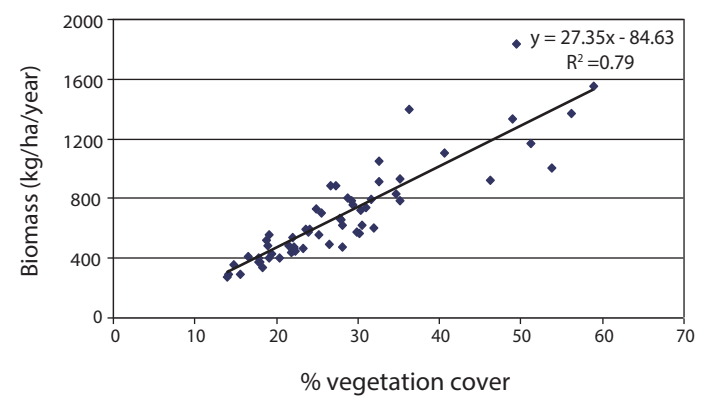

Fig. 4. Relationship between amounts of per cent of vegetation cover and biomass in the study area.

\section{RESULTS AND DISCUSSION}

The estimates done on the basis of observations on the current status of vegetation degradation reflect only what has happened till date. This kind of hazard assessment in the present work differs from risk and vulnerability assessment methods based on modeling, calculations and also taking into consideration the potential adverse situation that may arise in future. Indeed, most studies done in the world have based their estimation on the "present status' of vegetation degradation because the results could help better than other assessments for decision makers to prioritize areas need immediate remedial measures.

The Vegetation Degradation maps or information alone based on the present state of hazard derived from Per cent of vegetation cover are inadequate to show those areas which are more vulnerable to the current state of hazard. It requires a combination of indicators showing biomass of production especially ratio of actual biomass to potential biomass production to find precisely current state of hazard. The Sadra Basin model is an attempt of its kind for defining the real hazard of vegetation degradation and can be made applicable for other areas in Iran and elsewhere. The GIS analysis not only facilitated the model development but also allowed the evaluation of spatial analysis and hazard map production. The hazard map of the study area (Fig. 3)_shows different hazard classes.

Also results shows there is a relation between the precipitation map and amounts of biomass samples (Eq.4):

$$
\mathrm{Bio}=-115.36+(1.63) \times \mathrm{R}
$$

Bio: amount of biomass production (Kg per hectare per year); R: annual precipitation ( $\mathrm{mm}$ )

This result is in good agreement with other results regarding relation between annual precipitation and amounts of biomass in different regions of world (Le
Houerou 1965, Sims and Singh 1978, Wijngaarden 1985, Liang et al. 2003) indicating with increasing of precipitation amounts of biomass is also increased.

On the other hand Fig. 4 shows a significant relationship between two indicators used in the model. With increasing of per cent of vegetation cover amount of biomass is also increased. Studies in different regions of world have demonstrated that positive relationships exist between aboveground Biomass and cover of many plant species (Alaback 1986, Jonasson 1988, Chiarucci et al. 1999, Rttgermann et al. 2000, Muukkonen et al. 2006, MacDonald et al. 2012).

From the Fig. 3 a general conclusion can be derived that in the basin three hazard classes are observed which a larger proportion (89 \%) is under 'severe hazard' of vegetation degradation, where there is hardly any vegetation cover. The areas under moderate and very severe hazard classes have been found less extensive (9\% and $2 \%$ respectively) in the Sadra watershed. The natural vegetation cover reflects the climatic and soil conditions but is affected also by anthropogenic activity like encroachment for cultivation and grazing. In the region firewood provides fuel for the rural population and wood cutting continues unabated exposing the soil for greater erosion. The natural resources areas are encroached upon to increase urbanization and the areas of cultivation, especially for gardening. As a result, encroachment of the marginally hilly areas that were formerly the best grazing lands has become a high risk land use. At the same time, over grazing in the remaining rangelands gets accelerated by the ever increasing concentration of the livestock on rangelands. This replacement has been fast in the recent decade. Often all the woody plants, not leaving even the small sub shrubs, have been cut and have disappeared around the villages. Development of the new city in the basin, Sadra town, is one of the main causes of vegetation degradation during recent decade. Also grazing pressure seems to have become much intensive in the past couple of decades than it was before. It urgently requires proper 'rangeland management', based on grazing capacity. The implementation of management strategies is, of course, very difficult to introduce because of the socio-economic compulsions of the rural population.

Fig. 5 shows among different main indicators used in the model, the most effective indicator in vegetation degradation assessment of the study area is 'Ratio of actual biomass to Potential biomass production' while 'Per cent of vegetation cover' is the least effective indicator. 'Ratio of actual biomass to Potential biomass production' has been used more than the other two indicators for describ- 


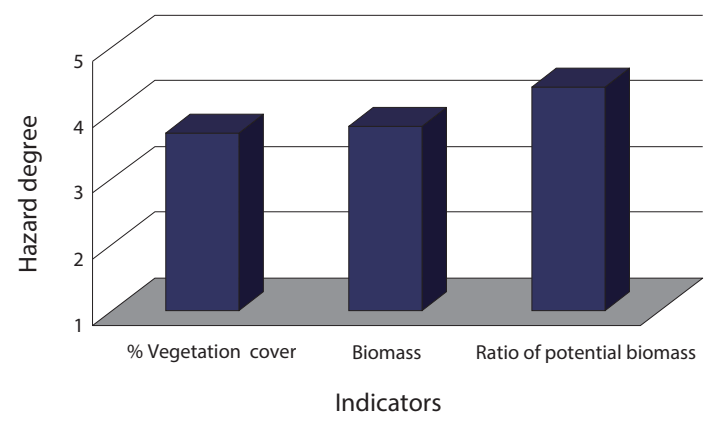

Fig.5. Average of Hazard Degrees of Main Indicators Used in the Model

ing current state of land degradation in the famous models of land degradation or desertification assessment (like: FAO/UNEP, GLASSOD and ASSOD). In both ASSOD and GLASSOD models, local experts assess the relative impact of a given amount of a certain type of degradation on the productivity of the soil. This kind of assessment seems to be more realistic in finding the degree of degradation because it is more related to its impact on soil productivity. In other words, the estimates of ASSOD take into account that a given amount of soil erosion is a more serious problem on poor, shallow soil than on deep, fertile soil.

\section{CONCLUSION}

Preparation of a Hazard Map is seen as a prerequisite for planning agricultural and environmental conservation. For the entire arid and semi arid parts of Iran, highly threatened by, vegetation degradation it is the need of the day.

The hazard assessment of vegetation degradation has been done in the present paper on the basis of three indicators showing current status of degradation. Also because of important rule of current biomass and per cent of vegetation cover showing current status of vegetation degradation, the objective was those indicators are used which describe the mentioned importance especially for biomass. Attempt has been made to focus on the vegetation degradation of natural plants of rangelands and forests and not on the agricultural systems. The thresholds (class limits) for the severity classes of these indicators have been established and subsequently the hazard map of vegetation degradation has been prepared in the GIS, deploying the new model. It is the first attempt of its kind in Iran and preparing such hazard maps may prove to be useful for regional planners, and policy makers for environmental strategies, not only in Southern Iran but also in other countries facing similar problem. However, this regional model can be made applicable for other countries only after modifying the classification of some of the indicators, based on the local conditions. The main results of the present paper are:

1. The hazard maps of three indicators of Per cent of vegetation cover, Biomass production and Ratio of actual biomass to Potential biomass production give a far better opportunity to distinguish the severity classes of hazard of vegetation degradation.

2. This kind of model helps to identify the areas need immediate attention for remedial measures. Areas under severe hazard (indicated in the hazard map) will be the areas needing immediate attention.

3. Considering all hazard classes it is concluded that the areas under severe hazard have a greater spread (89\%).

\section{ACKNOWLEDGEMENTS}

The authors are thankful to the Government Offices of Iran, for providing the data, maps and reports for this hazard assessment work.

\section{LITERATURE CITED}

Ahmadi H. 1995. Applied geomorphology. Tehran University Publication. 613p.

Ahmadi H, Abbas Abadi MR, Onagh M and Ekhtessasi MR. 2001. Quantitative assessment of desertification in Aghqalla and Gomishan Plain for creation of a regional model. Iranian J. Natural Resources 54 (1): 3-22.

Alaback PB. 1986. Biomass regression equations for understory plants in coastal Alaska: effects of species and sampling design on estimates. Northwest Science 60(2): 90-103.

Asadu C LA, Ike OO and Ugwuoke BO. 1999. Cattle grazing and environment in eastern Nigeria: Impact on soil physical properties. Outlook on Agriculture 28: 103-107.

Bonham CD. 1989. Measurements for terrestrial vegetation. John Wiley \& sons, Inc:New York. 338 p.

Bridges EM, Hannam ID, Oldeman LR, Penning de Vries FWT, Scherr SJ and Sombatpanit S .2001. Response to land degradation. Science publishers, INC, 510p.

Chiarucci A, Wilson JB, Anderson BJ \& De Dominicis V. 1999. Cover versus biomass as an estimate of species abundance: does it make a difference to the conclusions? Journal of Vegetation Science 10: 35-42. 
EEA. 1999. Environment in the European Union at the turn of the century, environmental assessment report No.2. Copenhagen: EEA.

FAO. 1994. Land degradation in South Asia: its severity causes and effects upon the people. FAO, UNDP and UNEP: Rome.

FAO/UNEP. 1984. Provisional methodology for assessment and mapping of desertification. Food and Agriculture Organization of the United Nations, Rome, 84p.

Feiznia S, Gooya AN, Ahmadi H and Azarnivand H. 2001. Investigation on desertification factors in Hossein-Abad Mish Mast plain and a proposal for a regional model. Journal of Biaban 6: 1-14.

Grumblatt J, Ottichilo WK and Sinange RK. 1992. A GIS approach to desertification assessment and mapping. Journal of Arid Environments 23: 81-102.

Jonasson S. 1988. Evaluation of the point intercept method for the estimation of plant biomass. Oikos 52: 10-106.

Kharin NG. 1986. Desertification assessment and mapping: a case study of Turkmenistan, USSR. Annals of Arid Zone 25: 1-17.

Kumar S. 1992. Assessment of vegetation degradation: status of methodological research. Annals of Arid zone 31: 5362.

Le Houerou, H. N. 1965. Improvement of natural pastures and fodder resources. Report to the Government of Libya. FAO, Rome. EPTA Rep. No. 1979. 46 p.

Le Houerou HN and Le Hoste CH. 1977. Rangeland production and annual rainfall relations in the Mediteranianian Basin and in the African Sahelo- Sudanian zone. Jour. of Range Management 30: 181-189.

Le Houerou HN. 1996. Climate change, drought and desertification. Journal of Arid Environments 34: 133-185.

Liang E, Vennetier M, Lin J, Shao X. 2003. Relationships between tree increment, climate and above-ground biomass of grass: a case study in the typical steppe, north China. Acta Oecologica 24: 87-94.

MacDonald R L, Burke JM, Chen HYH., and Prepas EE. 2012. Relationship between Aboveground Biomass and Percent Cover of Ground Vegetation in Canadian Boreal Plain Riparian Forests. Forest Science 58(1): 47-53.

Masoudi M. 2005. Risk assessment of land degradation in parts of Mond Basin, Southern Iran [PhD thesis]. Department of Environmental Science, Pune University, India.

Muukkonen P, Makipaa R, Laiho R, Minkkinen K, Vasander H. and Finer L. 2006. Relationship between biomass and percentage cover in understorey vegetation of boreal coniferous forests. Silva Fenn. 40:231-245.

Mwendra E J and Mohammad Saleem MA. 1996. Infiltration rates surface runoff and soil loss as influenced by grazing pressure in the Ethiopian highlands. Soil Use and Management 13: 29-35.

Oldeman LR, Hakkeling RTA and Sombroek WG. 1991. World map of the status of human-induced soil degradation: an explanatory note. Wageningen, International Soil Reference and Information Centre, Nairobi, UNEP, 27 p +3 maps. Revised edition.

Rttgermann M, Steinlein T, Beyschlag W \& Dietz H. 2000. Linear relationship between aboveground biomass and plant cover in low open herbaceous vegetation. Journal of Vegetation Science 11(1):145-148.

Van Lynden GWJ and Oldeman. 1997. Assessment of the status of human-induced soil degradation in south and southeast Asia (ASSOD). International Soil Reference and Information Centre.

Wijngaarden, W. van. 1985. Elephants-Trees-Grass-Grazers: relationships between climate, soil, vegetation and large herbivores in a semi-arid savanna ecosystem. ITC Publ. No. 4, Enschede, Netherlands.

Sims P L, Singh J S. 1978. The structure and function of ten western North American grasslands. III. Net primary production, turnover and efficiencies of energy capture and water use. Journal of Ecology 66: 573-597.

Singh S, Kar A, Joshi DC, Ram B, Kumar S, Vats PC, Singh N, Raina P, Kolarkar AS and Dhir RP. 1992. Desertification mapping in Western Rajasthan. Annals of Arid Zone 31: 237-246.

Taddese Y. 2001. Land degradation: A challenge to Ethiopia. Environmental Management 27: 815-824.

Zehtabian G, and Jafari R. 2002 Evaluation of water resources degradation in Kashan area using desertification model. Journal of Ecology 30: 19-30. 